\title{
MORPHOLOGICAL AND RADICAL PARAMETERS ASSOCIATED WITH THE SEEDLINGS QUALITY OF Anadenanthera peregrina (L.) Speg. IN DIFFERENT SUBSTRATES
}

\author{
Jéssica Costa de Oliveira ${ }^{1 *}$, Adalberto Brito de Novaes ${ }^{2}$ \\ ${ }^{1 *}$ Instituto Federal de Educação, Ciência e Tecnologia do Norte de Minas Gerais, Salinas, Minas Gerais, Brasil - \\ jessica.costaoliveira@ifnmg.edu.br \\ ${ }^{2}$ Universidade Estadual do Sudoeste da Bahia, Vitória da Conquista, Bahia, Brasil, adalberto.brito@globo.com
}

Received for publication: 17/06/2018 - Accepted for publication: 12/02/2020

\begin{abstract}
Resumo
Parâmetros morfológicos e radiciais associados à qualidade de mudas de Anadenanthera peregrina (L.) Speg. em diferentes substratos. Na presente pesquisa avaliou os efeitos de diferentes formulações de substratos sobre a qualidade de mudas de angico-vermelho (Anadenanthera peregrina (L.) Speg). Os substratos testados corresponderam a oito diferentes formulações: Bioplant ${ }^{\circledR}$, Carolina Soil, Casca de café, Fibra de coco e Vermiculita. Na fase de viveiro avaliaram-se: altura da parte aérea (H); diâmetro de colo (D); biomassas fresca e seca das partes aérea e sistema radical; índice de qualidade dickson (IQD); número de raízes regeneradas em tubos; e comprimento de raízes regeneradas em caixas. Na fase de campo avaliaramse: sobrevivência; diâmetro de copa; número de raízes laterais; e comprimento da raiz pivotante. Para a produção das mudas, utilizou-se o delineamento inteiramente casualizado com oito tratamentos e quatro repetições, e para o potencial de regeneração de raízes (P.R.R.), usou-se seis repetições. Em campo, o arranjo experimental constou de parcelas subdivididas, dispostas em blocos casualizados com quatro repetições. Mudas com maiores médias para grande parte das características avaliadas foram produzidas na formulação de substrato contendo $50 \%$ de Bioplant ${ }^{\circledR}+30 \%$ de casca de café $+20 \%$ de fibra de coco. Os valores de IQD mostraram-se positivamente relacionados às formulações contendo Bioplant ${ }^{\circ}$, casca de café e fibra de coco os quais, também se associaram positivamente com o P.R.R. As formulações contendo Bioplant ${ }^{\circledR}$, casca de café e fibra de coco resultaram em mudas com maior P.R.R., avaliado em caixas. Substratos contendo Bioplant ${ }^{\circledR}$, Carolina Soil, casca de café e fibra de coco favoreceram a produção de mudas com melhor sistema radical e consequentemente, melhor no campo.

Palavras-chave: angico-vermelho, potencial de regeneração de raízes, raízes.
\end{abstract}

\begin{abstract}
Morphological and Radical Parameters Associated with the Seedlings Quality of Anadenanthera peregrina (L.) Speg.in Different Substrates. In this research, we evaluated the effects of different substrate formulations on the quality of angico-vermelho seedlings (Anadenanthera peregrina (L.) Speg). The tested substrates corresponded to eight different formulations: Bioplant ${ }^{\circledR}$, Carolina Soil, Coffee husk, Coconut fiber and Vermiculite. In the nursery phase, the following were evaluated: height of the aerial part $(\mathrm{H})$; neck diameter (D); fresh and dry biomass of the aerial parts and radical system; dickson quality index (IQD); number of roots regenerated in tubes; and length of roots regenerated in boxes. In the field phase, the following were evaluated: survival; crown diameter; number of lateral roots; and length of the pivoting root. To produce seedlings, a completely randomized design with eight treatments and four replications was used, and for the evaluation of the root regeneration potential (P.R.R.), six replications were used. In the field, the experimental arrangement consisted of subdivided plots, arranged in randomized blocks with four replications. Seedlings with higher averages for most of the evaluated characteristics were produced in the formulation of substrate containing 50\% Bioplant ${ }^{\circledR}+30 \%$ coffee husk $+20 \%$ coconut fiber. The values related to the IQD were positively related to the substrate formulations containing Bioplant ${ }^{\circledR}$, coffee husk and coconut fiber, which were also positively associated with P.R.R. The substrate formulations containing Bioplant ${ }^{\circledR}$, coffee husk and coconut fiber resulted in seedlings with a higher P.R.R., evaluated in boxes. Substrates containing Bioplant ${ }^{\circledR}$, Carolina Soil, coffee husk and coconut fiberfavored the production of seedlings with a better radical system and, consequently, better in the field.
\end{abstract}

Keywords: angico-vermelho, root regeneration potential, roots.

\section{INTRODUCTION}

Anadenanthera peregrina (L.) Speg. (Fabaceae), popularly known as angico-vermelho, is considered a pioneer forest species with good natural regeneration and distribution over a vast area of the Brazilian territory, especially in regions with formations of semi-deciduous and deciduous forest (LORENZI, 2009). Also, according to this author, this tree shows moderate to rapid growth, and it can be used in projects for the recovery

FLORESTA, Curitiba, PR, v. 50, n. 3, p. 1467 - 1477, jul/set 2020.

Oliveira, J. C. et.al.

ISSN eletrônico 1982-4688

DOI: 10.5380/rf.v50 i3. 61577 
of degraded areas, in addition to other uses such as construction and charcoal production. Oliveira et al. (2012) state that the characteristics presented by this species confer great potential in the recovery of degraded areas.

For this and other purposes, Gomes et al. (1991) report that for the success of forestry programs it is essential that the seedlings have good quality so that they can resist the adverse conditions found in the field. When it comes to quality, this is guaranteed in large part, among other factors, by the composition of the substrate (SCHEER et al., 2010). However, according to these authors, commercial substrates do not always provide satisfactory amounts of nutrients and therefore, they must be enriched with fertilizers or organic matter for better efficiency. According to Dutra et al. (2013) the substrate must have physical and chemical characteristics that promote adequate growth of seedlings. Abreu et al. (2015) working with seedlings of Enterolobiumcontortisiliquum (Vell.) Morong (Fabaceae) in different containers, observed that the highest survival rates, after planting, were obtained with higher quality of the material evaluated in the nursery. Various studies and scientific research have sought to define the best methodologies, containers, substrates and fertilizations to produce forest seedlings, ensuring good adaptation and performance after planting (ELOY et al., 2013). This fact justifies the interest shown in the qualification of indicators for the survival and initial growth of seedlings in the field (CARNEIRO, 1995).

Seedling quality assessment can be carried out using morphological parameters and some physiological characteristics, such as the potential for root regeneration (P.R.R.) (CARNEIRO, 1995). According to this author, among the morphological characteristics, the height of the aerial part $(\mathrm{H})$, neck diameter (D), H/D ratio and dry and fresh biomass stand out. In addition, according to Alfenaset al., (2009), there is a need to include the characteristics of the root system, mentioning the quality, quantity and distribution of the roots on which the seedling growth depends. Given the above, the objective of the study was to evaluate by means of morphological and physiological parameters the effect of different substrate formulations on the quality of angicovermelhoseedlings (Anadenanthera peregrina (L.) Speg.).

\section{MATERIAL AND METHOD}

\section{Study location}

The research was conducted at the Forest Nursery and Laboratory of the Federal Institute of Northern Minas Gerais, municipality of Salinas/MG located at coordinates $16^{\circ} 10^{\prime} 13^{\prime}$ 'and $42^{\circ} 17^{\prime} 25$ ", with an altitude of $471 \mathrm{~m}$, with an annual temperature average of $22.7^{\circ} \mathrm{C}$ and annual rainfall of $700 \mathrm{~mm}$. The region has a semi-arid climate, whose predominant vegetation is characterized as Caatinga (IEF, 2019). The seeds were collected from matrices belonging to a fragment of native forest on the Campus of the same institution.

\section{Containers and substrates}

The conical model tube with $288.0 \mathrm{~cm}^{3}$ of volumetric capacity was used to produce the seedlings. As support, polypropylene trays with capacity for 54 tubes were used. The substrates used to produce the seedlings consisted of different formulations of an organic and chemical nature, as follows: T1: 100\% Bioplant $₫$; T2: 70\% Bioplant ${ }^{\circledR}+30 \%$ coffee husk; T3: $50 \%$ Bioplant ${ }^{\circledR}+30 \%$ coffee husk $+20 \%$ coconut fiber; T4: $100 \%$ carolina soil; T5: $70 \%$ carolina soil $+30 \%$ coffee husk; T6: $50 \%$ carolina soil $+30 \%$ coffee husk $+20 \%$ coconut fiber; T7: $50 \%$ coffee husk $+30 \%$ coconut fiber $+20 \%$ vermiculite; and T8: $33.3 \%$ coffee husk $+33.3 \%$ coconut fiber $+33.3 \%$ vermiculite.

Carolina Soil is a commercial substrate based on Sphagnum L. peat, expanded vermiculite, agroindustrial organic waste, dolomitic limestone, agricultural plaster and NPK fertilizer, and Bioplant ${ }^{\circledR}$ based on biostabilized pine bark.

As fertilization, all formulations received Osmocote slow release fertilizer (9-06-10) in the dosage of $5.0 \mathrm{~g} /$ liter of substrate. For the chemical characterization of the substrates, a sample of each formulation was sent to the Soil Fertility Laboratory of the IFNMG - Campus Januária, for chemical analysis (Table 01).

Table 1. Chemical characteristics of the substrates used in the production of angico-vermelho seedlings (Anadenanthera peregrina (L.) Speg.).

Tabela 1. Características químicas dos substratos utilizados na produção de mudas de angico-vermelho (Anadenanthera peregrina (L.) Speg.).

FLORESTA, Curitiba, PR, v. 50, n. 3, p. 1467 - 1477, jul/set 2020.

Oliveira, J. C. et.al.

ISSN eletrônico 1982-4688 


\begin{tabular}{|c|c|c|c|c|c|c|c|c|c|}
\hline & \multirow{2}{*}{ Characteristics $^{(1)}$} & \multicolumn{8}{|c|}{ Substrate $^{(2)}$} \\
\hline & & 1 & 2 & 3 & 4 & 5 & 6 & 7 & 8 \\
\hline $\mathrm{pH}$ & Water & 5,25 & 5,30 & 5,40 & 6,80 & 6,90 & 6,80 & 6,10 & 6,00 \\
\hline MO & $\mathrm{dag} / \mathrm{kg}$ & 14,60 & 13,20 & 13,90 & 8,00 & 10,80 & 9,50 & 11,00 & 10,30 \\
\hline $\mathrm{N}$ & $\mathrm{g} / \mathrm{kg}$ & 3,50 & 4,20 & 8,90 & 3,20 & 11,00 & 12,70 & 16,80 & 11,30 \\
\hline $\mathrm{P}$ & \multirow[b]{2}{*}{$\ldots \mathrm{mg} / \mathrm{dm}^{3} \ldots$} & 158,20 & 151,40 & 148,40 & 134,80 & 115,20 & 133,20 & 114,30 & 99,90 \\
\hline $\mathrm{K}$ & & 479,00 & 688,00 & 685,00 & 375,00 & 682,00 & 680,00 & 681,00 & 680,00 \\
\hline $\mathrm{Ca}$ & \multirow{7}{*}{.........cmolc/dm $\mathrm{dm}^{3} \ldots \ldots \ldots$} & 1,00 & 4,70 & 3,40 & 3,20 & 2,70 & 2,50 & 1,80 & 1,80 \\
\hline $\mathrm{Mg}$ & & 1,40 & 2,80 & 2,60 & 2,90 & 2,80 & 2,70 & 2,80 & 2,90 \\
\hline $\mathrm{Al}$ & & 0,04 & 0,02 & 0,05 & 0,00 & 0,00 & 0,00 & 0,00 & 0,00 \\
\hline $\mathrm{H}+\mathrm{Al}$ & & 2,33 & 1,78 & 1,54 & 0,84 & 0,76 & 1,02 & 1,80 & 1,35 \\
\hline SB & & 3,70 & 9,20 & 7,70 & 7,10 & 7,30 & 7,00 & 6,30 & 6,50 \\
\hline $\mathrm{t}$ & & 3,70 & 9,20 & 7,70 & 7,10 & 7,30 & 7,00 & 6,30 & 6,50 \\
\hline $\mathrm{T}$ & & 6,00 & 11,00 & 9,20 & 7,90 & 8,10 & 8,00 & 8,10 & 7,90 \\
\hline $\mathrm{V}$ & \multirow{2}{*}{$\ldots \% \ldots$} & 61,40 & 83,80 & 83,30 & 89,40 & 90,50 & 87,20 & 77,70 & 82,80 \\
\hline $\mathrm{m}$ & & 1,10 & 0,20 & 0,60 & 0,00 & 0,00 & 0,00 & 0,00 & 0,00 \\
\hline $\mathrm{Cu}$ & \multirow{4}{*}{$\mathrm{mg} / \mathrm{dm}^{3}$} & 0,20 & 0,10 & 0,20 & 0,10 & 0,10 & 0,10 & 0,20 & 0,10 \\
\hline $\mathrm{Fe}$ & & 62,20 & 71,80 & 49,60 & 51,50 & 35,00 & 32,50 & 32,30 & 52,30 \\
\hline $\mathrm{Mn}$ & & 9,30 & 8,60 & 5,40 & 7,40 & 3,80 & 4,20 & 1,90 & 2,70 \\
\hline $\mathrm{Zn}$ & & 1,70 & 1,60 & 2,00 & 3,20 & 1,70 & 2,00 & 1,00 & 0,50 \\
\hline
\end{tabular}

(1) $\mathrm{MO}=$ organicmatter; $\mathrm{t}=$ effectivecationexchangecapacity; $\mathrm{T}=$ cationexchangecapacity; $\mathrm{SB}=$ sum of bases; $\mathrm{m}=$ aluminumsaturation; $\mathrm{V}=$ base saturation; ${ }^{(2)} 1=100 \%$ Bioplant ${ }^{\circledR} ; 2=70 \%$ Bioplant ${ }^{\circledR}+30 \%$ casca de café; $3=50 \%$ Bioplant ${ }^{\circledR}+30 \%$ casca de café $+20 \%$ fibra de coco; $4=100 \%$ carolinasoil; $5=70 \%$ carolinasoil $+30 \%$ coffeehusk; $6=50 \%$ carolinasoil $+30 \%$ coffeehusk $+20 \%$ coconutfiber; $7=50$ $\%$ coffeehusk $+30 \%$ coconutfiber $+20 \%$ vermiculite $; 8=33,3 \%$ coffeehusk $+33,3 \%$ coconutfiber $+33,3 \%$ vermiculite

\section{Installation of the nursery phase and evaluation of morphological parameters}

When installing the experiment, the trays with the tubes were placed directly on the floor of the nursery. Subsequently, sowing was carried out manually, adding three seeds/container and on top of that, a mulch made up of the same substrate. The thinning was carried out when the seedlings were approximately $5.0 \mathrm{~cm}$ high.

After three months of sowing, seedlings were evaluated and systematically removed from the nursery for the respective measurements and weighing. Each sample consisted of eight seedlings in each plot in each treatment, in order to determine the morphological parameters: height of the aerial part (H); neck diameter (D); fresh biomass of the aerial part; fresh root biomass; dry biomass of the aerial part; and dry root biomass. To determine the morphological parameters, a thorough washing of the root system was carried out and then the seedlings were placed on a bench for a period of 12 hours. Soon after, the height of the aerial part (with a measuring tape) and the neck diameter (with digital pachymeter) were determined. Subsequently, the aerial parts and roots are separated to determine fresh biomass. Then, the seedlings were placed in paper bags, previously labeled and taken to an oven at $70^{\circ} \mathrm{C}$, where they remained until reaching constant dry mass. Then, the dry biomasses were determined by weighing on a precision digital scale.

\section{Assessment of Root Regeneration Potential - P.R.R.}

For the determination of the P.R.R. the seedlings after 90 days of sowing, were removed from the tubes and the radical system was subjected to careful washing and pruning of the lateral roots at a distance of approximately $4.0 \mathrm{~cm}$ from the axis of the pivoting root, the latter being also pruned to approximately $12 \mathrm{~cm}$ from the neck. Then, the following parameters were evaluated: a) total number of roots regenerated in tubes; and b) total length of roots regenerated in boxes.

\section{Test in tubes}

It was adopted the methodology proposed by Novaes et al. (2002), using transparent PET bottles without bottlenecks, with height and diameter showing, respectively, 25.0 and $10.0 \mathrm{~cm}$, and 1.9 liters of substrate 
volumetric capacity and covered with dark colored plastic canvas. As a substrate, Bioplant® based on biostabilized pine bark was used and watering was performed homogeneously in all containers six times a day. The number of regenerating roots was evaluated on alternate days in the period of 25 days after transplanting the seedlings into the tubes. The procedure adopted consisted of marking, by means of a marker pen, points on the transparent walls of the containers, exactly in the places touched by the ends of the regenerated roots.

\section{Test in boxes}

The length of the regenerated roots was evaluated using wooden boxes as containers, presenting dimensions of $70.0 \mathrm{~cm}$ in length, $30.0 \mathrm{~cm}$ in height and $7.0 \mathrm{~cm}$ in width and 14.7 liters of volumetric capacity. The Bioplant ${ }^{\circledR}$ substrate based on bio-stabilized pine bark was used, and watering was carried out daily in a homogeneous way in all containers. After transplanting the seedlings with the roots properly pruned, the boxes were arranged in a greenhouse, tilted to one side at an approximate angle of $30^{\circ}$ and covered with a dark colored plastic. The readings of the length of regenerated roots were taken weekly by the front glass wall, located at the bottom of the slope in the period of 42 days.

\section{Radical performance and characteristics in the field}

The experiment was installed in a degraded Permanent Preservation Area (APP), located on the "Umburanas" farm, belonging to the Federal Institute of Northern Minas Gerais, municipality of Salinas / MG, occupying 0.2 ha in the $3.0 \times 3.0 \mathrm{~m}$ spacing. The soil preparation consisted of opening holes with dimensions of $40.0 \times 40.0 \times 40.0 \mathrm{~cm}$. The fertilization consisted of the localized application of $200 \mathrm{~g}$ of simple superphosphate. The planting was carried out manually and then the seedlings were irrigated by applying approximately four liters of water per plant, with the remaining irrigations (4 liters per plant) carried out three times a week until the thirty days.

The performance of plants in the field was evaluated over a 90-day period by determining the parameters: survival index and crown diameter. The field evaluation was expected to occur at six months of age, however, it was decided to carry out at 90 days in view of the pessimistic forecasts of the climatic conditions of the region for the following months. At six months, as predicted, a considered mortality was found, which compromised one of the four blocks of the experiment, even so, it was decided to carry out the evaluation of the radical system considering only three blocks. Thus, a seedling per plot was selected and removed from the soil in each repetition, in order to evaluate the parameters: length of the pivoting root; and number of lateral roots. To remove each plant, a $60.0 \mathrm{~cm}$ diameter circle was dug around the roots and a $40.0 \mathrm{~cm}$ deep ditch was opened in order to detach the intact clod containing the entire plant's radical system. Then, the clod was carefully dismantled, the roots were subjected to a cleaning process on the field and the plants were taken to the laboratory for their respective evaluations.

\section{Treatments and statistical procedures}

The eight treatments were constituted from the combination of the different components of substrates. In the nursery stage to evaluate the morphological parameters, the experimental design was adopted entirely at random with four replications showing 32 plots, each consisting of 25 seedlings, making a total of 800 seedlings throughout the experiment. For the step regarding the determination of the P.R.R. in tubes, a completely randomized design was used, with eight treatments and six replications presenting 48 plots, containing one seedling each and considered as an experimental unit, making a total of 48 seedlings. The same statistical procedure was considered in the box test, where eight units were used, corresponding to the eight treatments and seven repetitions, consisting of a seedling, making a total of 56 seedlings. For survival and development in the field, a randomized block design with four replications and six seedlings per plot was adopted, making a total of 192 seedlings.

For all the results obtained, the data were subjected to analysis of variance through the System for Statistical Analysis, SAEG 9.1. The averages obtained were compared using the Tukey test at 95\% probability.

\section{RESULTS}

\section{Aerial part height (H) and neck diameter (D)}

The substrate formulations T1 (100\% Bioplant $\left.{ }^{\circledR}\right)$, T2 (70\% Bioplant ${ }^{\circledR}+30 \%$ coffee husk) and T3 $\left(50 \%\right.$ Bioplant ${ }^{\circledR}+30 \%$ coffee husk $+20 \%$ coconut fiber $)$ presented the highest averages for the variable height of the aerial part and neck diameter of the seedlings, despite not showing statistical differences between them (Figure 1). The lowest averages for these variables were obtained from the T8 formulation (33.3\% coffee husk + $33.3 \%$ coconut fiber $+33.3 \%$ vermiculite).

FLORESTA, Curitiba, PR, v. 50, n. 3, p. 1467 - 1477, jul/set 2020. 

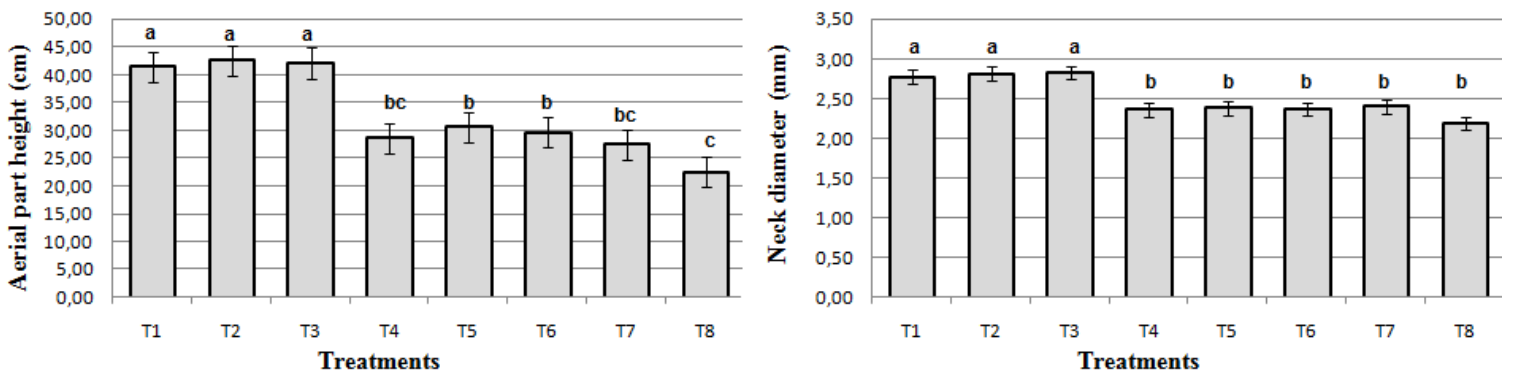

$\mathrm{T} 1=100 \%$ Bioplant $\AA ; \mathrm{T} 2=70 \%$ Bioplant $\AA+30 \%$ coffeehusk; $\mathrm{T} 3=50 \%$ Bioplant ${ }^{\circledR}+30 \%$ coffeehusk $+20 \%$ coconutfiber; $\mathrm{T} 4=100 \%$ carolinasoil; $\mathrm{T} 5=70 \%$ carolinasoil $+30 \%$ coffeehusk; $\mathrm{T} 6=50 \%$ carolinasoil $+30 \%$ coffeehusk $+20 \%$ coconutfiber; $\mathrm{T} 7=50 \%$ coffeehusk $+30 \%$ coconutfiber $+20 \%$ vermiculite; $\mathrm{T} 8=33,3 \%$ coffeehusk $+33,3 \%$ coconutfiber $+33,3 \%$ vermiculite

Figure 1 - Average values of height of the aerial part $(\mathrm{H})$ and diameter of neck $(\mathrm{D})$ of angico-vermelho seedlings (Anadenanthera peregrina (L.) Speg.), 90 days after sowing. Averages followed by the same letter, in each column, do not differ, by Tukey's test, at $5 \%$ probability.

Figura 1 - Valores médios de altura da parte aérea (H) e diâmetro de colo (D) de mudas de angico-vermelho (Anadenanthera peregrina (L.) Speg.), 90 dias após a semeadura. Médias seguidas pela mesma letra, em cada coluna, não diferem entre si, pelo teste de Tukey, a $5 \%$ de probabilidade.

\section{Fresh and dry biomass}

In Figure 2, fresh biomass data from the aerial and root parts are presented. Averages with higher values for fresh biomass of the aerial part were obtained from seedlings produced in formulations T1, T2 and T3. When compared with the other formulations, it was possible to detect statistical differences. For fresh root biomass, the highest values were obtained when formulations T1 and T2 were used, although there was no statistical difference between the other formulations.
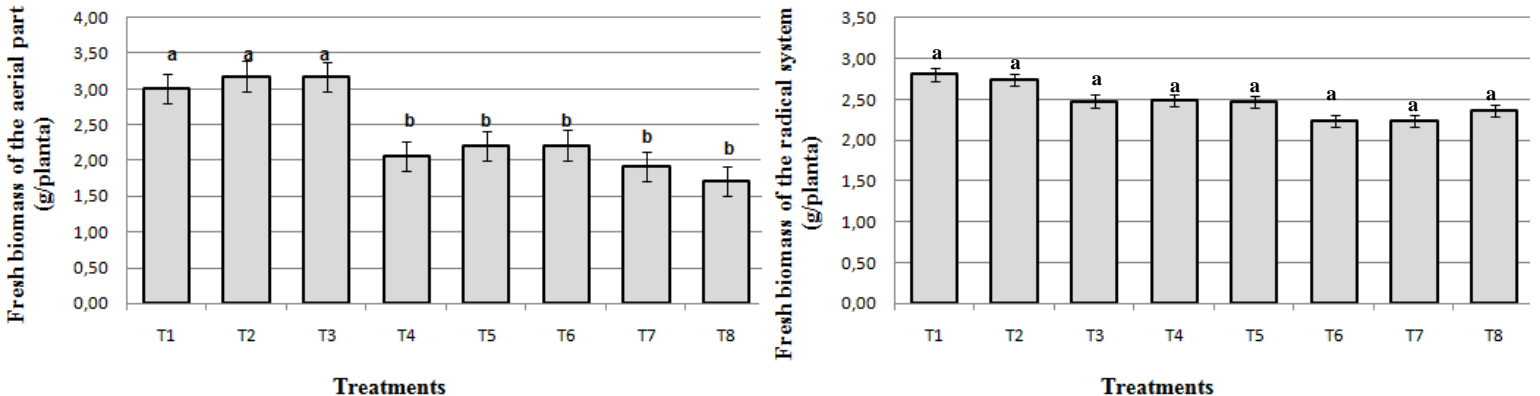

$\mathrm{T} 1=100 \%$ Bioplant ${ }^{\circledR} ; \mathrm{T} 2=70 \%$ Bioplant ${ }^{\circledR}+30 \%$ coffeehusk; $\mathrm{T} 3=50 \%$ Bioplant ${ }^{\circledR}+30 \%$ coffeehusk $+20 \%$ coconutfiber; $\mathrm{T} 4=100 \%$ carolinasoil; $\mathrm{T} 5=70 \%$ carolinasoil $+30 \%$ coffeehusk; $\mathrm{T} 6=50 \%$ carolinasoil $+30 \%$ coffeehusk $+20 \%$ coconutfiber; $\mathrm{T} 7=50 \%$ coffeehusk $+30 \%$ coconutfiber $+20 \%$ vermiculite $; \mathrm{T} 8=33.3 \%$ coffeehusk $+33.3 \%$ coconutfiber $+33.3 \%$ vermiculite.

Figure 2 - Average values of fresh biomass of the aerial parts and roots of angico-vermelho seedlings (Anadenanthera peregrina (L.) Speg.), 90 days after sowing. Averages followed by the same letter, in each column, do not differ, by Tukey's test, at $5 \%$ probability.

Figura 2 - Valores médios de biomassa fresca das partes aérea e raiz de mudas de angico-vermelho (Anadenanthera peregrina (L.) Speg.), 90 dias após a semeadura. Médias seguidas pela mesma letra, em cada coluna, não diferem entre si, pelo teste de Tukey, a 5\% de probabilidade.

The data of dry biomass of aerial parts and radical system are presented in Figure 3. Averages with higher values for these variables were obtained from formulations T1, T2 and T3, although no statistical differences were found between them. The lowest averages of dry biomass, both in the aerial part and in the radical system, were obtained from the seedlings produced in the T8 and T6 formulations (50\% carolina soil + $30 \%$ coffee husk $+20 \%$ coconut fiber). 

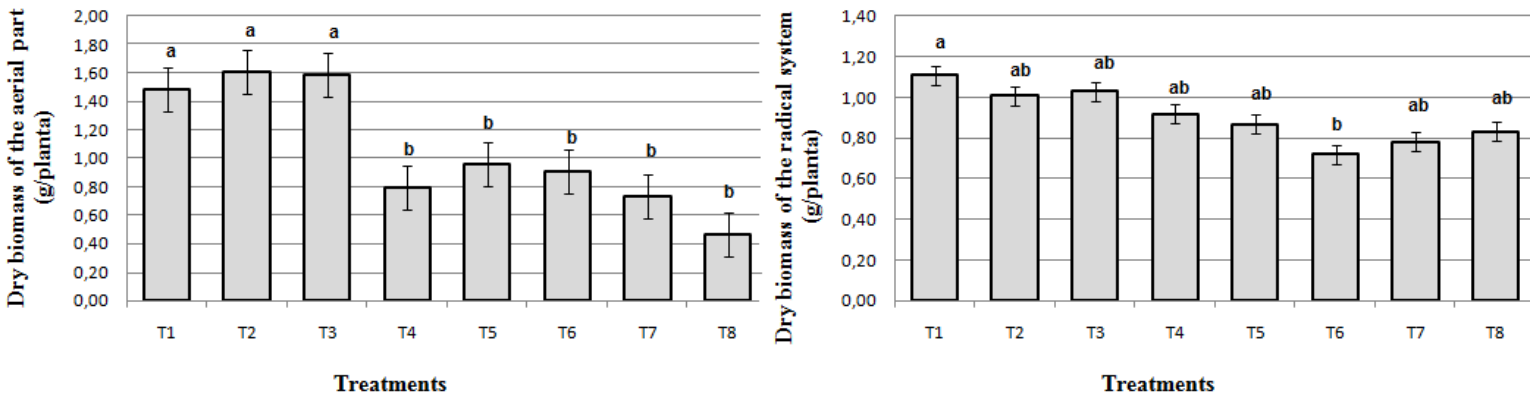

$\mathrm{T} 1=100 \%$ Bioplant $\AA ; \mathrm{T} 2=70 \%$ Bioplant $\AA+30 \%$ coffeehusk; $\mathrm{T} 3=50 \%$ Bioplant ${ }^{\circledR}+30 \%$ coffeehusk $+20 \%$ coconutfiber; $\mathrm{T} 4=100 \%$ carolinasoil; $\mathrm{T} 5=70 \%$ carolinasoil $+30 \%$ coffeehusk; $\mathrm{T} 6=50 \%$ carolinasoil $+30 \%$ coffeehusk $+20 \%$ coconutfiber; $\mathrm{T} 7=50 \%$ coffeehusk $+30 \%$ coconutfiber $+20 \%$ vermiculite $; \mathrm{T} 8=33.3 \%$ coffeehusk $+33.3 \%$ coconutfiber $+33.3 \%$ vermiculite

Figure 3 - Average values of dry biomass of aerial parts, roots and total of angico-vermelho (Anadenanthera peregrina (L.) Speg.) Seedlings, 90 days after sowing. Averages followed by the same letter, in each column, do not differ, by Tukey's test, at 5\% probability.

Figura 3 - Valores médios de biomassa seca das partes aérea, raiz e total de mudas de angico-vermelho (Anadenanthera peregrina (L.) Speg.), 90 dias após a semeadura. Médias seguidas pela mesma letra, em cada coluna, não diferem entre si, pelo teste de Tukey, a 5\% de probabilidade.

\section{Dickson's Quality Score (IQD)}

In Figure 4, data related to the IQD are presented. According to the averages test, there is no statistical difference between them. However, the averages from formulations T1, T2 and T3 stood out among the others. The lowest averages for this parameter were obtained from seedlings produced in formulations T6, T7 (50\% coffee husk $+30 \%$ coconut fiber $+20 \%$ vermiculite) and $\mathrm{T} 8$.

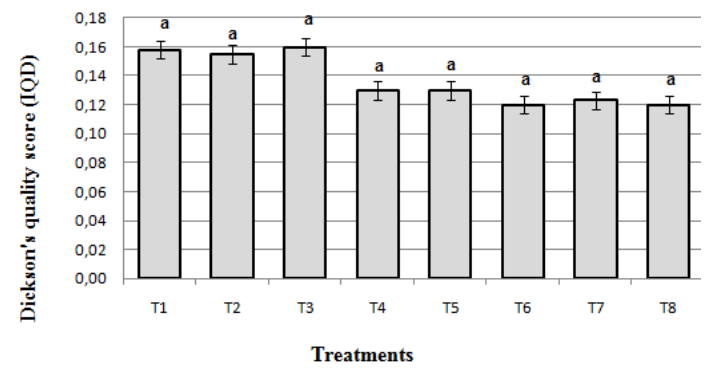

$\mathrm{T} 1=100 \%$ Bioplant ${ }^{\circledR} ; \mathrm{T} 2=70 \%$ Bioplant ${ }^{\circledR}+30 \%$ coffeehusk; $\mathrm{T} 3=50 \%$ Bioplant ${ }^{\circledR}+30 \%$ coffeehusk $+20 \%$ coconutfiber; $\mathrm{T} 4=100 \%$ carolinasoil; $\mathrm{T} 5=70 \%$ carolinasoil $+30 \%$ coffeehusk; $\mathrm{T} 6=50 \%$ carolinasoil $+30 \%$ coffeehusk $+20 \%$ coconutfiber; $\mathrm{T} 7=50 \%$ coffeehusk $+30 \%$ coconutfiber $+20 \%$ vermiculite $\mathrm{T} 8=33.3 \%$ coffeehusk $+33.3 \%$ coconutfiber $+33.3 \%$ vermiculite

Figure 4 - Average values of the Dickson Quality Index (DQI) of angico-vermelho seedlings (Anadenanthera peregrina (L.) Speg.), 90 days after sowing. Averages followed by the same letter, in each column, do not differ, by Tukey's test, at $5 \%$ probability.

Figura 4 - Valores médios do Índice de Qualidade de Dickson (IQD) de mudas de angico-vermelho (Anadenanthera peregrina (L.) Speg.), 90 dias após a semeadura. Médias seguidas pela mesma letra, em cada coluna, não diferem entre si, pelo teste de Tukey, a $5 \%$ de probabilidade.

\section{Root Regeneration Potential (P.R.R.)}

The results corresponding to the root regeneration potential (P.R.R) evaluated in tubes and boxes are shown in Figure 5. For P.R.R. evaluated in tubes, the seedlings produced in the T4 formulation (100\% carolina soil) showed the highest averages. The formulations T1 and T2 made the average seedlings similar and inferior to those of the T4 formulation, but superior to the others. In production using the T7 and T8 formulations, the values obtained were lower, however, the lowest average was for the seedlings produced in the T6 formulation, with a significant difference for the other formulations.

As for the length of roots regenerated in boxes, the seedlings produced in formulation T3 showed the highest average, followed by those produced in formulations T2, T7, T5 (70\% carolina soil $+30 \%$ coffee husk) and T4, with no significant differences for these formulations. Even so, there was a superiority in the seedlings

FLORESTA, Curitiba, PR, v. 50, n. 3, p. 1467 - 1477, jul/set 2020.

Oliveira, J. C. et.al.

ISSN eletrônico 1982-4688

DOI: $10.5380 /$ rf.v50 i3. 61577 
produced when formulations T2 and T3 were used, as was also the case for the morphological characteristics (Figures 1 and 2).

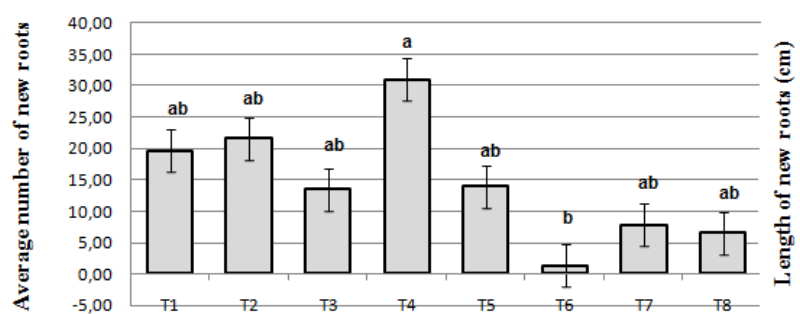

Treatments

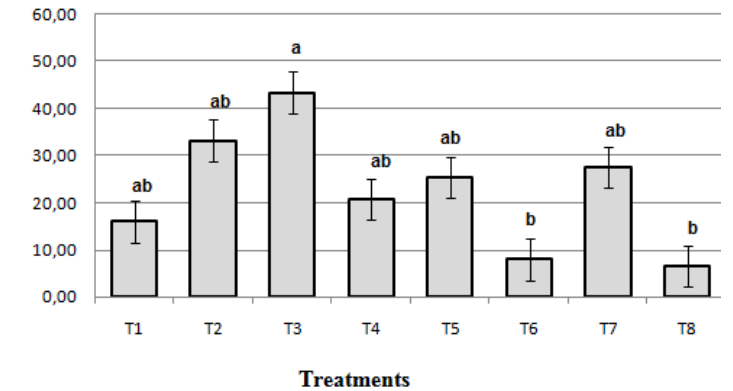

Treatments

$\mathrm{T} 1=100 \%$ Bioplant $\AA ; \mathrm{T} 2=70 \%$ Bioplant ${ }^{\circledR}+30 \%$ coffeehusk; $\mathrm{T} 3=50 \%$ Bioplant ${ }^{\circledR}+30 \%$ coffeehusk $+20 \%$ coconutfiber; $\mathrm{T} 4=100 \%$ carolinasoil; $\mathrm{T} 5=70 \%$ carolinasoil $+30 \%$ coffeehusk; $\mathrm{T} 6=50 \%$ carolinasoil $+30 \%$ coffeehusk $+20 \%$ coconutfiber; $\mathrm{T} 7=50 \%$ coffeehusk $+30 \%$ coconutfiber $+20 \%$ vermiculite; $\mathrm{T} 8=33.3 \%$ coffeehusk $+33.3 \%$ coconutfiber $+33.3 \%$ vermiculite .

Figure 5 - Number and length of regenerated roots of angico-vermelho seedlings (Anadenanthera peregrina (L.) Speg.), Respectively in tubes and boxes at 25 and 42 days after transplantation. Averages followed by the same letter, in each column, do not differ, by Tukey's test, at $5 \%$ probability.

Figura 5 - Número e comprimento de raízes regeneradas de mudas de angico-vermelho (Anadenanthera peregrina (L.) Speg.), respectivamente em Tubos e Caixas aos 25 e 42 dias após o transplante. Médias seguidas pela mesma letra, em cada coluna, não diferem entre si, pelo teste de Tukey, a 5\% de probabilidade.

\section{Plant survival in the field and radical characteristics}

The data related to the survival index and crown diameter of the seedlings are shown in Figure 6. Seedlings produced in formulations T1 and T6 had the highest survival rates, with those produced in the other formulations having a slightly lower index, the lowest being obtained with T7.

For the crown diameter, seedlings produced in formulations T1, T2 and T3, presented the highest values. Formulations T7 and T8, on the other hand, enabled the lowest averages.
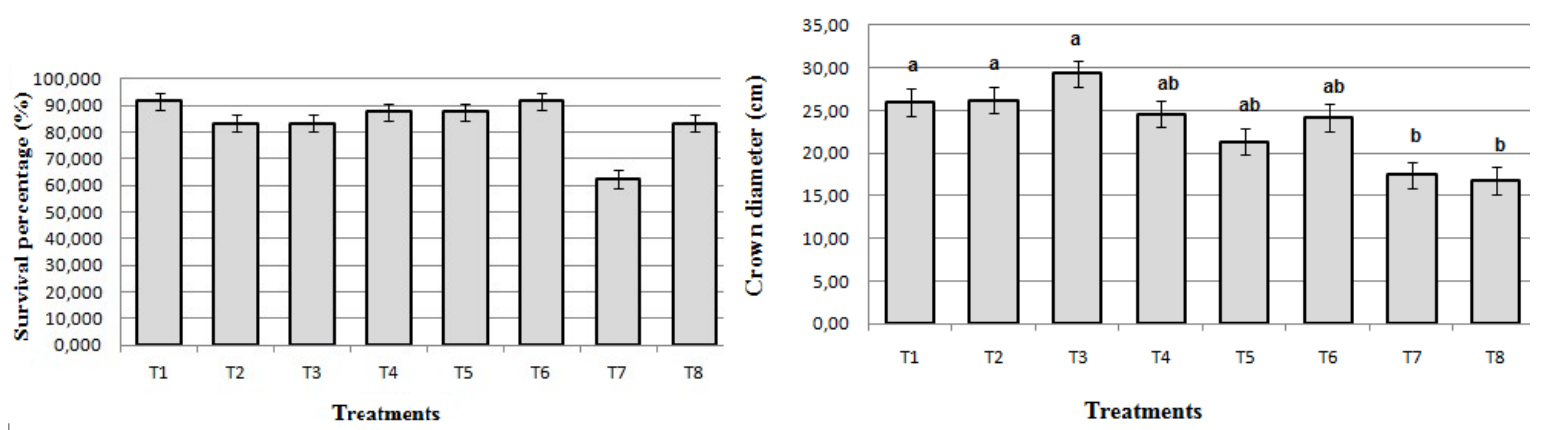

$\mathrm{T} 1=100 \%$ Bioplant $\AA ; \mathrm{T} 2=70 \%$ Bioplant $\AA+30 \%$ coffeehusk; $\mathrm{T} 3=50 \%$ Bioplant ${ }^{\circledR}+30 \%$ coffeehusk $+20 \%$ coconutfiber; $\mathrm{T} 4=100 \%$ carolinasoil; $\mathrm{T} 5=70 \%$ carolinasoil $+30 \%$ coffeehusk; $\mathrm{T} 6=50 \%$ carolinasoil $+30 \%$ coffeehusk $+20 \%$ coconutfiber; $\mathrm{T} 7=50 \%$ coffeehusk $+30 \%$ coconutfiber $+20 \%$ vermiculite; $\mathrm{T} 8=33.3 \%$ coffeehusk $+33.3 \%$ coconutfiber $+33.3 \%$ vermiculite.

Figure 6 - Average values and development of crown area of angico-vermelho (Anadenanthera peregrina (L.) Speg.) plants in the period corresponding to 90 days. Averages followed by the same letter, in each column, do not differ, by Tukey's test, at $5 \%$ probability.

Figura 6 - Valores médios e desenvolvimento de Área decopa de plantas de angico-vermelho (Anadenanthera peregrina (L.) Speg.) no período correspondente a 90 dias. Médias seguidas pela mesma letra, em cada coluna, não diferem entre si, pelo teste de Tukey, a 5\% de probabilidade.

\section{Radical system and root distribution in the field}

Figure 7 presents data on variables, number of lateral roots and length of pivoting root. The seedlings corresponding to the T3 formulation stood out, presenting the highest average of lateral roots. Seedlings with lower means of lateral roots were obtained in formulation T2. As for the root length, the T6 and T7 formulations showed seedlings with higher averages, even though the substrate did not influence their growth.

FLORESTA, Curitiba, PR, v. 50, n. 3, p. 1467 - 1477, jul/set 2020.

Oliveira, J. C. et.al.

ISSN eletrônico 1982-4688

DOI: $10.5380 /$ rf.v50 i3. 61577 

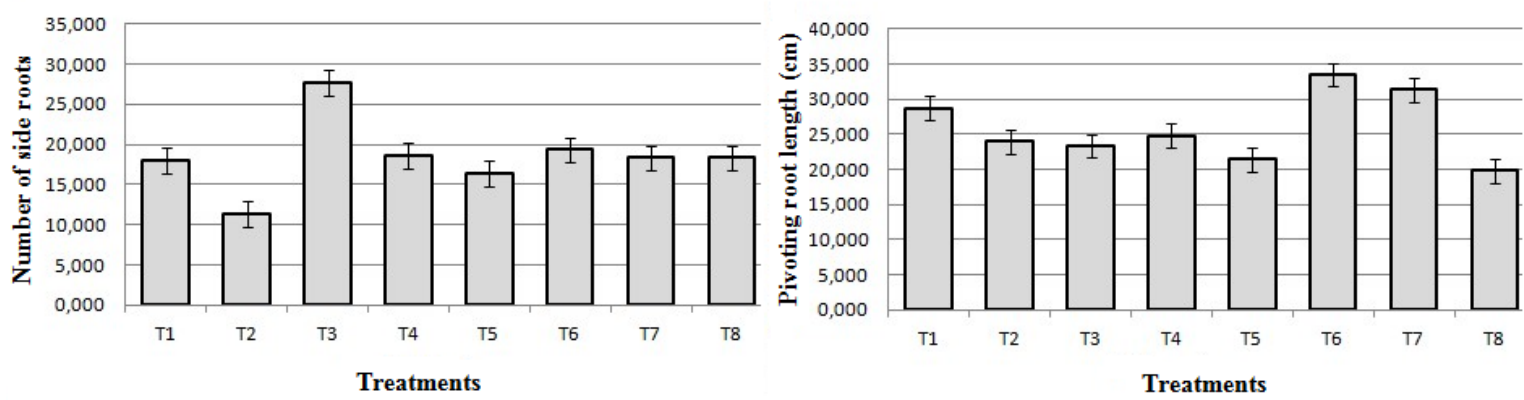

$\mathrm{T} 1=100 \%$ Bioplant ${ }^{\circledR} ; \mathrm{T} 2=70 \%$ Bioplant ${ }^{\circledR}+30 \%$ coffeehusk; $\mathrm{T} 3=50 \%$ Bioplant ${ }^{\circledR}+30 \%$ coffeehusk $+20 \%$ coconutfiber; $\mathrm{T} 4=100 \%$ carolinasoil; $\mathrm{T} 5=70 \%$ carolinasoil $+30 \%$ coffeehusk; $\mathrm{T} 6=50 \%$ carolinasoil $+30 \%$ coffeehusk $+20 \%$ coconutfiber; $\mathrm{T} 7=50 \%$ coffeehusk $+30 \%$ coconutfiber $+20 \%$ vermiculite $\mathrm{T} 8=33.3 \%$ coffeehusk $+33.3 \%$ coconutfiber $+33.3 \%$ vermiculite.

Figure 7 - The average number of lateral roots and in pivoting root length of angico-vermelho seedlings (Anadenanthera peregrina (L.) Speg.), 180 days after planting.

Figura 7 - Valores médios do número de raízes laterais e comprimento da raiz pivotante em mudas de angicovermelho (Anadenanthera peregrina (L.) Speg.), 180 dias após o plantio.

\section{DISCUSSION}

\section{Aerial part height (H) and neck diameter (D)}

The highest values for the height of the aerial part were found in the seedlings of formulations T1, T2 and T3. In treatments $\mathrm{T} 2$ and T3, the substrate containing coffee husk and coconut husk powder provided a positive effect on seedling performance. These results corroborate those obtained by Caldeira et al. (2013), which also observed in Chamaecristadesvauxii (Collad.) Killip (Fabaceae) seedlings, positive effect of substrates containingin natura coffee straw.

As for the neck diameter variable (D), it was possible to observe a superiority of the averages obtained in the seedlings produced in the formulations T1, T2 and T3, with emphasis on the last two containing coffee husks. Similar results were observed by Faria et al. (2013), when using substrates consisting of in naturacoffee straw and bovine manure in the production of Senna alata (L.) Roxb (Fabaceae) seedlings.

As observed in the present work, there is a need for studies that use alternative substrates from organic residues in order to provide a higher content of nutrients and, thus, an improvement in the quality of seedlings. Averages with lower values, for all evaluated parameters, fitted to the seedlings produced in formulation T8, showing the lack of nutrients, also observed in formulation $\mathrm{T} 1$.

\section{Fresh and dry biomass}

As for the fresh biomass of the aerial part of the seedlings, formulations T1, T2 and T3 containing coffee husk and coconut husk powder made the highest values possible. Similar results were also observed by Souza et al. (2015), working with seedlings of Eugenia involucrata DC. (Myrtaceae), produced on substrates containing coconut shell powder. The T4 formulation made the lowest values possible, probably justified by the low nutritional content. For fresh root biomass the substrate corresponding to formulation T1 or combined with formulations T2 and T3 containing coffee husk and coconut husk powder, promoted greater weight gains of fresh biomass.

For the dry biomass of the aerial part of the seedlings, although there was no statistical difference, the highest values were obtained when the substrates corresponding to formulations T1, T2 and T3 were used. These results indicate the vigor of seedlings in these substrates and confirm once again the importance of their components in the development of seedlings. According to Paiva et al. (2011), substrates with a higher content of organic compounds provide greater moisture retention and provide most of the essential nutrients for seedling development in its initial stage, a statement confirmed in the present work when analyzing formulations T2 and T3 containing bark coffee and coconut shell powder in its formulation. As for dry root biomass, the highest average was obtained from seedlings produced in the substrate corresponding to the formulation $\mathrm{T} 1$, which probably favored the production of more fibrous roots and, consequently, reduced the number of physiologically active roots. Similar results with this substrate were observed by Dutra et al. (2013), working with seedlings of Peltophorumdubium (Spreng.) Taub (Fabaceae). Carneiro (1995) draws attention to the difference in weight between these two variables, given that the physiologically active roots, in greater proportion, are high in water, their dry biomass being almost negligible, but of great importance for survival and initial growth in the field.

FLORESTA, Curitiba, PR, v. 50, n. 3, p. 1467 - 1477, jul/set 2020.

Oliveira, J. C. et.al.

ISSN eletrônico 1982-4688

DOI: $10.5380 /$ rf.v50 i3. 61577 
Seedlings corresponding to the formulation T4, Carolina Soil, even though coffee peel and coconut shell powder were added, presented the lowest values for both variables. The substrates formulated only with coffee husk, coconut husk powder and vermiculite, in different proportions, were also not satisfactory when analyzing this variable. The combination of these substrates, considering their physical characteristics, may have compromised their aggregation and, consequently, the development of the roots, in addition to reducing their water holding capacity.

\section{Dickson's Quality Score (IQD)}

For the IQD, formulations T1, T2 and T3 enabled the highest values, with emphasis on formulation T3. These results confirm the superiority of the substrate containing in its formulation only Bioplant ${ }^{\circledR}$ pure or combined with coffee husk and coconut husk powder. Corroborating with the present study, Baldinet al. (2015), researching angico-vermelho seedlings in different volumes of substrates, found that treatments with higher IQD values also showed higher averages for most of the variables evaluated.

\section{Root Regeneration Potential (P.R.R.)}

Despite the highest root regeneration averages being obtained in the seedlings of formulation T4, formulations T1 and T2 enabled similar means of P.R.R., above the other treatments, thus suggesting a better performance of these seedlings in the field. Values similar to those found in this work using tubes, were obtained by Oliveira Júnior et al. (2011), with seedlings of Eucalyptus urophylla S. T. Blake (Myrtaceae).

Still considering the P.R.R. with respect to the development of roots in boxes, seedlings corresponding to formulation T3 presented the highest averages, followed by formulation T2. It is noteworthy that these two formulations produced seedlings with higher averages for practically all the morphological characteristics evaluated in the present study, including those evaluated in the field. The results obtained in this research corroborate those obtained by Samôret al. (2002), who reported that larger morphological parameters result in a higher number of regenerated roots from Anadenantheramacrocarpa (Benth.) Brenan (Fabaceae) seedlings.

The lowest values for root length corresponded to the seedlings produced in the T6 and T8 formulations, which also occurred when tubes were used, demonstrating the influence of the substrate on the emission of the number and length of new roots. Novaeset al. (2002), observed in their work with Pinus taeda L. (Pinaceae) that seedlings with greater capacity for root regeneration, evaluated in Boxes, also showed a higher rate of survival and development in the field, demonstrating the importance of this test in the evaluation of P.R.R.

\section{Field performance of plants and radical characteristics}

The highest survival rates of seedlings in the field were obtained from formulations T1 and T6. The other formulations, on the other hand, allowed slightly lower rates, with emphasis on the seedlings from the T7 formulation with lower survival rate, emphasizing that they presented the lowest P.R.R. values in the nursery, suggesting a reliability for this parameter in the prediction of seedling survival after the planting. Bonfimet al. (2009) also found that P.R.R. demonstrated to be a good survival indicator for seedlings of PterogynenitensTul. (Fabaceae).

The seedlings corresponding to formulations T1, T2 and T3, presented the largest crown diameters and therefore, were considered to be of better quality according to the parameters evaluated in the nursery. In the present study, the average crown diameter, considering all plants in the experiment, ranged from 16.77 to 29.33 $\mathrm{cm}$, showing an average of $23.24 \mathrm{~cm}$ after three months in the field. Marcuzzoet al. (2015), researching angicovermelho seedlings in moderately compacted soils with no natural regeneration, found an average of $18.8 \mathrm{~cm}$ for the crown diameter in 24-month-old plants. The results obtained by these authors show the good performance of the plants in the field, also verified in the present study.

\section{Root distribution in the field}

As for the number of lateral roots, it was observed that the T3 formulation stood out, allowing the seedlings to have greater quantities, confirming the superiority of this formulation for most of the parameters evaluated in the nursery, including for P.R.R. that considers the length of new roots. Plants with a greater number of lateral roots explore a larger area of soil and, consequently, will have significant gains in establishment and development. Abreu et al. (2014) found that better root formation promotes higher growth rates in the field. For Oliveira et al. (2006) seedlings with a high percentage of root emissions achieve greater adaptation to environmental stress, particularly regarding the scarcity of water and nutrients.

As for the length of the pivoting root, it was possible to observe that the T6 and T7 formulations showed seedlings with longer root lengths, even though the substrate did not influence their growth. This fact may be related to the species itself, considering that the angico-vermelho naturally has a deeper radical system. These

FLORESTA, Curitiba, PR, v. 50, n. 3, p. 1467 - 1477, jul/set 2020. 
results are corroborated by Cunha et al. (2005), who when evaluating the quality of seedlings of Handroanthusimpetiginosus (Mart. Ex DC) Mattos (Bignoniaceae), did not observe the effect of the substrate on the length of the main root.

\section{CONCLUSIONS}

- $\quad$ The substrate containing $50 \%$ Bioplant ${ }^{\circledR}+30 \%$ coffee husk $+20 \%$ coconut fiber provided better quality characteristics to the seedlings, both in nursery and in the field, being indicated to produceangico-vermelho seedlings for planting under the conditions tested.

- The substrate formulations containing Bioplant ${ }^{\circledR}$, coffee husk and coconut fiber resulted in seedlings with a higher P.R.R.

- Greater radical growth and survival in the field was obtained from the composition of substrates containing Bioplant ${ }^{\circledR}$, Carolina Soil, coffee husk and coconut fiber.

- The values related to the IQD of the seedlings were shown to be positively related to the substrate formulations containing Bioplant ${ }^{\circledR}$, coffee husk and coconut fiber which were also positively associated with P.R.R.

\section{REFERENCES}

ABREU, A. H. M.; LELES, P. S. S.; MELO, L. A.; FERREIRA, D. H. A. A.; MONTEIRO, F. A. S. Produção de mudas e crescimento inicial em campo de Enterolobiumcontortisiliquum produzidas em diferentes recipientes. Revista Floresta, Curitiba-PR, v. 45, n. 1, p. 141-150, 2015.

ALfENAS, A. C.; ZAUZA, E. A. V.; MAFIA, R. G.; ASSIS, T. F. de. Clonagem e doenças do eucalipto. Viçosa-MG: Editora UFV, 2009, 442 p.

BALDIN, T.; CONTE, B.; DENARDI, L.; DE MORAES, R.; SALDANHA, C. W. Crescimento de mudas de angico-vermelho em diferentes volumes de substratos. Pesquisa Florestal Brasileira, Colombo-PR, v. 35, n. 82, p. 129-133, 2015.

BONFIM, A. A.; NOVAES, A. B.; SÃO JOSÉ, A. R.; GRISI, F. A. Avaliação morfológica de mudas de madeira-nova (Pterogynenitens Tull.) produzidas em tubetes e sacos plásticos e de seu desempenho no campo. Revista Floresta, Curitiba-PR, v. 39, p. 33-40, 2009.

CALDEIRA, M. V. W.; DELARMELINA, W. M.; FARIA, J. C. T.; JUVANHOL, R. S. Substratos alternativos na produção de mudas de Chamaecristadesvauxii. .Revista Árvore, Viçosa-MG, v.37, n.1, p.31-39, 2013.

CARnEIRO, J. G. A. Produção e controle de qualidade de mudas florestais. Curitiba-PR: Campos/UENF. UFPR/FUPEF, 1995. $451 \mathrm{p}$.

CUNHA, A. O.; ANDRADE, L. A. de.; BRUNO, R. L. A.; SILVA, J. A. L. da.; SOUZA, V. C. de. Efeitos de substratos e das dimensões dos recipientes na qualidade das mudas de Tabebuia impetiginosa (Mart. Ex. D.C.) Standl. Revista Árvore, Viçosa-MG, v. 29, n. 4, p. 507-516, 2005.

DUTRA T. R.; MASSAD M. D.; SARMENTO, M. F. Q.; OLIVEIRA, J. C. Substratos alternativos e métodos de quebra de dormência para produção de mudas de canafístula. Revista Ceres, Viçosa-MG, v. 60, n. 1, p. 072078, 2013.

ELOY, E.; CARON, B. O.; SCHMIDT, D.; BEHLING, A.; SCHWERS, L.; ELLI, E. F. Avaliação da qualidade de mudas de Eucalyptusgrandisutilizando parâmetros morfológicos. Revista Floresta, Curitiba-PR, v. 43, n. 3, p. 373-384, 2013.

FARIA, J. C. T.; CALDEIRA, M. V. W.; DELARMEliNA, W. M.; ROCHA, R. L. F. Uso de resíduos orgânicos na produção de mudas de Senna alata (L.) Roxb. Ecologia e Nutrição Florestal, Santa Maria-RS, v.1, n.3, p.133-146, 2013.

Instituto Estadual de Florestas/MG - IEF. A Cobertura Vegetal de Minas Gerais. Disponível em: http://www.ief.mg.gov.br/florestas. Acesso em 16 de julho de 2019.

LORENZI, H. Árvores Brasileiras: Manual de identificação e cultivo de plantas arbóreas nativas do Brasil. 3. ed. Editora São Paulo: Instituto Plantarum, 2009, 384 p.

FLORESTA, Curitiba, PR, v. 50, n. 3, p. 1467 - 1477, jul/set 2020.

Oliveira, J. C. et.al.

ISSN eletrônico 1982-4688

1476

DOI: 10.5380/rf.v50 i3. 61577 
GOMES, J. M.; COUTO, L.; BORGES, R. C. G.; FONSECA, E. P. Efeito de diferentes substratos na produção de mudas de Eucalyptusgrandis W. Hill exMaiden, em "Win-Strip". Revista Árvore, Viçosa-MG, v. 15, n. 1, p. 35-42, 1991.

MARCUZZO, S. B.; ARAÚJO, M. M.; GASPARIN, E. Plantio de espécies nativas para restauração de áreas em unidades de conservação: um estudo de caso no sul do Brasil. Revista Floresta, Curitiba-PR, v. 45, n. 1, p. 129 $-140,2015$.

NOVAES, A. B.; CARNEIRO, J. G. de A.; BARROSO, D. G.; LELES, P. S. dos S. Avaliação do potencial de regeneração de raízes de mudas de Pinus taeda L. produzidas em diferentes tipos de recipientes e o seu desempenho no campo. Revista Árvore, Curitiba-PR, v. 26, n. 6, p. 675-681, 2002.

OLIVEIRA, A. S.; COELHO, E. F.; FACCIOLI, G. G. Manejo básico da irrigação na produção de fruteiras. Brasília-DF: LK, 2006, 136 p.

OLIVEIRA, K. S.; OLIVEIRA, K. S.; ALOUFA, M. A. I. Influência de substratos na germinação de sementes de Anadenanthera colubrina (Vell.) Brenan em condições de casa de vegetação. Revista Árvore, Viçosa-MG, v. 36, n. 6, p. 1073-1078, 2012.

OLIVEIRA JUNIOR; O. A. de; CAIRO, P. A. R.; NOVAES, A. B. de. Características morfofisiológicas associadas à qualidade de mudas de Eucalyptusurophylla produzidas em diferentes substratos. Revista Árvore, Viçosa-MG, v. 35, n. 6, p.1173- 1180, 2011.

PAIVA, E.P.; MAIA, S.S.S.; CUNHA, C.S.M.; COELHO, M.F.B.; SILVA, F.N. Composição do substrato para o desenvolvimento de mudas de manjericão (Ocimumbasilicum L.). Revista Caatinga, Mossoró-RN, v. 24, n. 4, p. 62-67, 2011.

SAMÔR, O. J. M.; CARNEIRO, J. G. A.; BARROSO, D. G.; LELES, P. S. S. Qualidade de mudas de angico e sesbânia produzidas em diferentes recipientes e substratos. Revista Árvore, Viçosa-MG, v.26, n.2, p.209-215, 2002.

SCHEER, M. B.; CARNEIRO, C.; SANTOS, K. G. Substratos à base de lodo de esgoto compostado na produção de mudas de Parapiptadeniarigida (Benth.) Brenan. ScientiaForestalis, Piracicaba-SP, v.38, n.88, p.637-644, 2010.

SOUZA, P. L. T,; VIEIRA, L. R.; BOLIGON, A. A.; VESTENA, S. Produção e qualidade de mudas de Eugenia involucrata DC. em diferentes substratos. Revista Biociências, Taubaté-SP, v. 21, n. 1, p. 100-108, 2015. 